\title{
Buenos Aires en carnaval: los corsos del barrio de Villa Devoto en la década de $1930^{1}$
}

\section{Buenos Aires in carnival: corsos in Villa Devoto neighborhood in the 1930s}

\author{
Erica Cubilla \\ Universidad Nacional de General Sarmiento (Argentina) \\ ericaecubilla@gmail.com
}

\begin{abstract}
Resumen
Este artículo indaga las celebraciones de carnaval en la Buenos Aires de los años treinta, tomando como caso de estudio los corsos realizados en el barrio de Villa Devoto. Examinamos, por un lado, la morfología de las celebraciones y el papel de las asociaciones barriales en su organización y analizamos, por otro lado, las negociaciones que se libraron entre la Municipalidad, las asociaciones vecinales y los habitantes de Villa Devoto para llevar a cabo dicho festejo.
\end{abstract}

\section{Palabras clave}

Sociabilidad; carnavales; Buenos Aires; espacio público; década de 1930

\begin{abstract}
This article inquires into the carnival celebrations in the 1930s Buenos Aires, taking as a case study the corsos wich were carried out in Villa Devoto neighborhood. We examined, on the one hand, the morphology of the celebrations and the role of the neighbour associations in their organization. On the other hand, we analyze the negotiations held between the Municipality, the neighbour associations and the inhabitants from Villa Devoto to carry out these celebrations.
\end{abstract}

\section{Keywords}

Sociability; carnivals; Buenos Aires; public space;1930s decade

\footnotetext{
${ }^{1}$ Este artículo forma parte de mi tesis de Maestría realizada en el Posgrado en Ciencias Sociales IDESUNGS (2018). Agradezco a los evaluadores anónimos y a quienes leyeron borradores de este escrito en diferentes grupos de discusión y aportaron sugerencias y comentarios enriquecedores. La Junta de Estudios Históricos de Villa Devoto y la Biblioteca "Presidente Roque Saenz Peña" posibilitaron el acceso a documentos y bibliografía secundaria sobre Villa Devoto.

Esta obra está sujeta a la Licencia Reconocimiento-NoComercial-CompartirIgual 4.0 Internacional de Creative Commons. http://creativecommons.org/licenses/by-nc-sa/4.0/ (cc) BY-NC-sa
} 


\section{Buenos Aires en carnaval: los corsos del barrio de Villa Devoto en la década de 1930}

En el verano de 1930 Emilio Gauna, un joven de 21 años que vivía en el barrio de Saavedra en Capital Federal, había ganado mil pesos en una carrera de caballos y se disponía a gastarlos junto a sus amigos en una aventura que se extendería durante las tres noches del carnaval porteño. Gauna, Larsen, Maidana, Antúnez, Pegoraro, Massantonio y el doctor Valerga iniciaron el recorrido en Villa Devoto. Viajaron hasta allí en tren y al descender se encontraron con el bullicio típico de estos festejos, las personas disfrazadas caminaban por las calles del barrio y las máscaras corrían asustando a los transeúntes. Estuvieron en el corso, compraron bebidas en un almacén y recorrieron la Plaza Arenales. En el camino, Emilio y sus compañeros, se cruzaron con una bulliciosa y alegre murga que animaba a los vecinos con bombos, tambores y platillos. Más adelante, algunos jóvenes se lanzaban serpentina y se vaciaban entre sí sus pomos con espuma. Cuando el grupo se cansó de este ruidoso y alborotado espectáculo, ingresaron a un club a beber unas copas. Luego, al retirarse del lugar, se subieron a una victoria tirada por dos caballos y continuaron su aventura por los corsos de Avenida Rivadavia, Villa Luro, Flores y Nueva Pompeya. Durante los tres días de carnaval vieron un sinnúmero de máscaras y disfraces, y visitaron clubes, bares, almacenes y cabarets, en donde consumieron comida y alcohol. Evidentemente, los corsos barriales de la década del treinta representaban una alternativa tentadora de diversión para muchos porteños en esas calurosas semanas de verano.

Esta anécdota pertenece al relato ficcional de Adolfo Bioy Casares en " $E l$ sueño de los héroes". ${ }^{2}$ Allí el escritor rememora las vivencias de siete amigos durante tres noches de carnaval. En dicha novela se vislumbra un festejo concurrido, fresco, variado y divertido. Esta narración literaria nos muestra algunas pinceladas del desarrollo de los corsos barriales durante los años treinta en la Capital Federal. Por su parte, los documentos de la época nos describen la fiesta en la plaza central, el desfile de murgas, orfeones y centros gauchescos, las familias disfrazadas que posaban en palcos caracterizados con algún motivo pintoresco, los bailes en los clubes y cines, y la febril actividad del comercio barrial puesta al servicio de quienes festejaban hasta las primeras horas de la madrugada.

En este artículo nos proponemos indagar las celebraciones de carnaval durante la década de 1930 en aquel barrio de la ciudad donde Emilio Gauna y sus amigos comenzaron su aventura, Villa Devoto. Nos preguntamos ¿en qué consistían los carnavales barriales? ¿Cómo y dónde se realizaban? ¿Quiénes participaban de los festejos y quiénes eran sus organizadores? ¿Es posible detectar alguna modificación en esta celebración pública a lo largo de la década? ¿Qué nos dicen esas fiestas sobre la relación entre algunas asociaciones barriales y el Estado municipal? Argumentaré, en primer lugar, que los festejos de carnaval en los años treinta involucraban a buena parte de los habitantes del barrio ya fuera como parte del público que disfrutaba las celebraciones y/o como organizadores comprometidos con el éxito de las diferentes actividades planificadas para tal fin. En relación con esto último,

${ }^{2}$ Adolfo Bioy Casares. El sueño de los héroes. Buenos Aires, Editorial Losada, 1954. 


\section{Erica Cubilla}

procuro demostrar, en segundo lugar, que la organización del carnaval representó una instancia de negociación entre ciertos habitantes de Villa Devoto y la Municipalidad de la Ciudad de Buenos Aires. De hecho, como se verá, los carnavales constituyeron una coyuntura favorable para que las asociaciones vecinales pudieran erigirse como representantes del conjunto de vecinos del barrio frente a las autoridades municipales.

Cabe recordar que en la década de 1930, la Capital Federal estaba organizada como una municipalidad y subdividida en 26 circunscripciones. La comuna era gobernada por un intendente nombrado por el presidente de la nación con acuerdo del Senado. Asimismo, funcionaba un Concejo Deliberante compuesto por 30 miembros, elegidos, a través del sufragio obligatorio y secreto de todos los varones nativos $\mathrm{y}$, a través del sufragio secreto y optativo de todos los extranjeros. ${ }^{3} \mathrm{El}$ intendente designado por Agustín P. Justo entre 1932 y 1938, fue Mariano de Vedia y Mitre. En el noroeste de la ciudad y en el límite con la provincia de Buenos Aires, Villa Devoto conformaba la circunscripción 15. Su territorio se había anexado a la metrópoli luego de la Ley de Federalización de 1880 y el primer loteo de terrenos se realizó en 1889, año a partir del cual comenzó un lento pero sostenido proceso de desarrollo edilicio.

A inicios de los años treinta los límites de aquel loteo inicial se habían desdibujado. En Villa Devoto, las edificaciones se habían multiplicado y la población creció de 48.381 habitantes en 1909 a 146.717 en $1936 .{ }^{4}$ La vida asociativa se diversificó y extendió a la par del crecimiento urbano. A mediados de la década de 1930, funcionaban al menos 10 sociedades de fomento, 20 clubes deportivos, 2 bibliotecas públicas, 6 sociedades étnicas, congregaciones religiosas católicas, protestantes y judías, el Círculo de Profesionales de Villa Devoto, el Círculo de Obreros Católicos y la Liga de Comerciantes de Villa Devoto, entre otras organizaciones. Asimismo, la zona contaba con, al menos, 10 escuelas públicas y privadas, una comisaria y funcionaba también allí la Alcaldía de Contraventores. ${ }^{5}$ Para 1935 las asociaciones vecinales y algunos vecinos reconocidos habían logrado la ampliación e inauguración del Hospital Abel Zubizarreta, un proyecto que databa de principios del siglo XX y que se concretó gracias a la labor conjunta del municipio y las asociaciones, puesto que estas últimas aportaron para la recaudación de fondos, donando los ingresos obtenidos precisamente en los corsos barriales.

\footnotetext{
${ }^{3}$ Según documenta Luciano De Privitellio, este sistema se desarrolló entre 1917 y 1941 y fue “...el resultado de la reforma de la Ley Orgánica Municipal aprobada en agosto de 1917. (...) El período se cierra en 1941 cuando el presidente en ejercicio, Ramón S. Castillo puso fin a este régimen institucional al intervenir el Poder Legislativo de la ciudad y reemplazarlo por una Comisión Vecinal elegida por el presidente con acuerdo del Senado." Luciano De Privitellio. Vecinos y ciudadanos. Política y sociedad en la Buenos Aires de entreguerras. Buenos Aires, Siglo XXI Editores, 2003, p. 18.

${ }^{4}$ Municipalidad de la Ciudad de Buenos Aires. Cuarto Censo General de Población. Municipalidad de la Ciudad de Buenos Aires. 22 de octubre de 1936. Tomo I: "Informe preliminar", p. 100.

${ }^{5}$ En otro trabajo analizo las representaciones de la prensa barrial y las asociaciones vecinales sobre la presencia de la Alcaldía en Villa Devoto: Erica Cubilla. “¿Alcaldía de Contraventores o 'Cárcel de Villa Devoto?': representaciones en disputa en torno a un barrio porteño en los años treinta”, en: Sandra Gayol y Silvana Palermo (Eds.). Política y cultura de masas en la Argentina de la primera mitad del siglo XX. Los Polvorines, Ediciones UNGS, 2018, pp. 125-148.
} 


\section{Buenos Aires en carnaval: los corsos del barrio de Villa Devoto en la década de 1930}

Al calor del desarrollo de las industrias culturales, se habían instalado en Villa Devoto 7 cines, de los cuales 4 también funcionaban como salas de teatro y salones de bailes o fiestas. La prensa barrial adquirió un rol fundamental para la proyección y circulación de ideales de respetabilidad, distinción social y costumbres familiares que se estimaban decentes. Específicamente, en 1930 comenzó a publicarse el Boletín de la Asociación de Fomento de Villa Devoto y en 1932 el periódico semanal Noticias Devotenses (ND). Este último, bajo la dirección de Lorenzo Blanco y Jorge Figueroa, se distribuía semanalmente por correo a quienes pagaran una suscripción mensual de \$1. Ambos directores pertenecían a familias reconocidas de Villa Devoto y estaban emparentados con personas destacadas -como Altube y Buschiazzo- por ser algunos de los primeros habitantes de la zona. En su primer número el periódico enunciaba sus principales objetivos: acompañar y dar a conocer el crecimiento y la cultura del barrio. La prensa local pretendió contribuir así a dotar al barrio de un perfil propio, en sus páginas se iba articulando una auto-representación por cierto elogiosa: un barrio que se preciaba de su prosperidad, del esfuerzo y trabajo de sus residentes, que se convertía en un mundo laboral propicio para profesionales y comerciantes, capaz de ofrecer espacios de participación pública y brindar alternativas de entretenimiento familiares. $N D$ constituye, junto con la Memoria del Departamento Ejecutivo de la Municipalidad de la Ciudad de Buenos Aires (MDEMCBA), el corpus documental principal de este artículo.

Las celebraciones que aquí nos ocupan, los carnavales, han sido indagadas por numerosos especialistas. Historiadores, sociólogos y antropólogos estudiaron el rol de estas fiestas en la sociedad, la cultura y la política. ${ }^{6}$ Asimismo, el uso de diferentes escalas geográficas permitió echar luz sobre las particularidades que adquieren estas expresiones en diversos contextos. ${ }^{7}$ Los corsos que analizamos en

\footnotetext{
${ }^{6}$ Mijail Bajtin. La cultura popular en la Edad Media y en el Renacimiento. Buenos Aires, Alianza, 1994. Peter Burke. "La traducción de la cultura: el carnaval en dos o tres mundos", en Peter Burke (Ed.). Formas de historia cultural, Madrid, Alianza Editorial, 2000, pp. 191-206. Roberto DaMatta. Carnavales, malandros y héroes. Hacia una sociología del dilema brasileño. México, FCE, 2002. Umberto Eco, Et. Al. Carnaval! México, FCE, 1989. Alejando Espinosa Patrón. "Aproximación a una teoría de la fiesta del Rey Momo a partir de la triada comunicación, cultura y carnaval". Palabra Clave, Vol. 13, $\mathrm{N}^{\circ} 1,2010$, pp. 175-188. Juan Antonio Flores Martos. "Un continente de carnaval: etnografía crítica de carnavales americanos". Anales del Museo de América, 2001, pp. 29-58.

${ }^{7}$ Entre otros: Milita Alfaro. Memorias de la bacanal: vida y milagros del carnaval montevideano (18501950). Montevideo, Ediciones de la Banda Oriental, 2008. Andrés Bisso, Sociabilidad, política y movilización. Cuatro recorridos bonaerenses (1932-1943). Buenos Aires, CEDINCI- Editorial Buenos Libros, 2009. Milton Godoy Orellana. "Carnaval, disciplinamiento cultural y respuestas populares en Chile (Norte Chico, 1840-1900), en Ernesto Bohoslavsky y Milton Godoy Orellana, (Eds.), Construcción estatal, orden oligárquico y respuestas sociales. Argentina y Chile, 1840-1930, Buenos Aires, UNGS/Prometeo, 2010, pp. 121-148. Oscar Chamosa. "Lúbolos, Tenorios y Moreiras: reforma liberal y cultura popular en el carnaval de Buenos Aires de la segunda mitad del siglo XIX", en Hilda Sábato y Alberto Lettieri (Comps.), La vida política en la Argentina del siglo XIX. Armas, votos y voces, Buenos Aires, FCE, 2003, 115-135. Ricardo Falcón. "La larga batalla por el carnaval. La cuestión del orden social, urbano y laboral en el Rosario del S. XIX". Anuario de la Escuela de Historia, n ${ }^{\circ} 14$, segunda época, Rosario, UNR- Editora, 1989. Ricardo Falcón. "Rituales, fiestas y poder (una aproximación historiográfica a un debate sobre su pasado y presente). Estudios Sociales, Revista universitaria semestral, $\mathrm{n}^{\circ}$ 18, año X, Santa Fe, 2000, pp. 89-101. Leandro Losada. "Del carnaval al corso de Palermo: los ritos sociales de la élite porteña en la belle époque (1880-1910)". Jahrbuch für
} 


\section{Erica Cubilla}

este artículo se desenvolvieron en tiempos poco auspiciosos para estos festejos. Durante los años treinta los gobiernos conservadores implementaron medidas destinadas a controlar las actividades y demostraciones que tenían lugar en el espacio público. Por esto, esta indagación no puede desatender la estrecha relación entre los carnavales y la política. Algunos estudiosos le dan centralidad a esta temática en distintas ciudades de Argentina. Por ejemplo, Diego Roldán argumenta que, en Rosario, entre 1930 y 1932, se agudizó la preocupación en torno a estas fiestas y afirma que "las fuerzas del orden intentaron controlar las potencialidades revulsivas de las celebraciones". 8 A partir de 1932, según afirma el autor, como consecuencia de la gradual merma en la concurrencia, las autoridades municipales procuraron recuperar los corsos barriales prohibidos anteriormente. Para ello dispusieron que se pudiera festejar en los diferentes vecindarios y "el carnaval se descentralizó definitivamente en 1933. La intendencia dejó a los vecinos la organización de los corsos". ${ }^{9}$

En referencia a estos eventos en la Provincia de Buenos Aires Andrés Bisso examina, aunque de un modo diferente, la presencia de la política en los festejos, a partir de un original examen sobre los disfraces utilizados en los corsos de Chascomús, Lezama, La Plata, Berisso, Ensenada, Dolores y Berazategui entre 1936 y 1940. Esta exploración de lo que denomina las "identidades prestadas" a través de la vestimenta y su análisis sobre el accionar del gobierno de Manuel Fresco, le permiten definir al carnaval como "una instancia más de negociación entre los vecinos y los dirigentes provinciales y municipales, en un registro similar que el de las conmemoraciones patrias y otras fiestas cívicas". ${ }^{10}$ Según Bisso, las "discusiones y el rol del Estado pueden perfilarse desde un observatorio al que hasta ahora se le ha prestado poca atención, como lo es su relación con el ocio y la sociabilidad". ${ }^{11}$ Como se observa, durante estos años en Rosario y en la provincia de Buenos Aires, los carnavales se transformaron en un acontecimiento privilegiado para indagar las relaciones entre los ciudadanos, funcionarios municipales 0 autoridades provinciales. Resta analizar entonces que sucedió a nivel barrial con estas fiestas que se extendieron en un buen número de ciudades de Argentina.

\footnotetext{
Geschichte Lateinamerikas, Alemania, Böhlau Verlag, 2007, pp. 259-280. Diego Roldán. "Imágenes, juegos, rituales y espacios. Las Interacciones socioculturales entre elites y sectores populares durante la entreguerras. La "incultura en Rosario (Argentina)". História, São Paulo, 28, (2), 2009, pp. 683- 714. Diego Roldán. La invención de las masas. Ciudad, corporalidades y culturas. La Plata, Facultad de Humanidades y Ciencias de la Educación (UNLP), capítulo XI, 2015, pp. 223-237.

8 Diego Roldán. "Imágenes de un juego social y simbólico. Los carnavales rosarinos entre 1900 y 1945". Estudios Sociales, revista universitaria semestral, № 40, año XXI, Santa Fe, primer semestre 2011, pp. 139.

${ }^{9}$ Ídem, p. 141.

${ }^{10}$ Andrés Bisso. “ ¿El de gaucho o el de Tom Mix? Reflexiones políticas a partir de los horizontes de identidades prestadas en disfraces y personificaciones lúdicas en la provincia de Buenos Aires durante los carnavales de la época fresquista, 1936-1940", en Andrés Bisso, Kahan, Emmanuel y Sessa, Leandro (Comps), Formas políticas de celebrar y conmemorar el pasado (1930-1943), La Plata, Ceraunia, 2014, p. 110.

${ }^{11}$ Ibídem., p. 115.
} 


\section{Buenos Aires en carnaval: los corsos del barrio de Villa Devoto en la década de 1930}

Como ya mencionamos, los carnavales porteños de la década del treinta tuvieron lugar en una ciudad donde el uso del espacio público era objeto de cuidadosa atención por parte del gobierno nacional. Marianne González Alemán ha documentado el intento de Agustín P. Justo de reglamentar y prescribir el juego político callejero a través de un edicto policial en mayo de 1932. Según la autora, los debates que se plantearon sobre el uso de la calle y el derecho de reunión expresaban "la convicción según la cual los ciudadanos no se habían mostrado aptos a la socialización y que la sociedad se encontraba pervertida desde su interior por elementos inasimilables". ${ }^{12}$ Si bien en apariencia el edicto parece dirigido sólo a cuestiones políticas, esta indagación nos advierte sobre la necesidad de atender a la intervención de las autoridades en los festejos de carnaval. Dicho de otro modo, exige interrogarnos sobre el modo en que el Estado, a través de sus medidas y funcionarios, intentó moldear no sólo las prácticas políticas en las calles sino también las actividades culturales o de ocio.

Con el fin de desentrañar los interrogantes planteados sobre las celebraciones de carnaval en Villa Devoto, sus protagonistas y su relación con la política, este artículo está dividido en tres apartados. En el primero, reseñamos las particularidades del carnaval en la Ciudad de Buenos Aires y el surgimiento de los corsos barriales. En el segundo apartado, examinamos los festejos en Villa Devoto y reconstruimos su morfología, sus actores y modos de participación. Por último, indagamos la relación y la interacción entre las asociaciones, los habitantes del barrio y la municipalidad en el contexto de dichas fiestas.

\section{El carnaval porteño: "del centro a los barrios"}

Desde la década de 1870 los carnavales de la Ciudad de Buenos Aires se desarrollaban durante varios días, usualmente en los meses de febrero y marzo e incluían diferentes actividades. Según sostiene Oscar Chamosa, éstos tuvieron una relevancia y una magnitud comparables a los festejos de Río de Janeiro e incluso "se puede afirmar que el carnaval de Buenos Aires reunía una asistencia más numerosa y diversa que su par carioca". ${ }^{13}$ La sucesión de juegos con agua, desfiles de comparsas y los bailes en los clubes demostraban, según sostiene este historiador, el carácter multiclasista y multiétnico del carnaval porteño. Para 0. Chamosa, con la Ley de Federalización primero, y la expansión urbana después, la fiesta perdió dicho carácter multiclasista ${ }^{14}$ ya que "la estratificación social de los distintos barrios se vio

\footnotetext{
12 Marianne González Alemán. “¿Qué hacer con la calle? La definición del espacio público porteño y el edicto policial de 1932". Boletín del Instituto de Historia Argentina y Americana Dr. Emilio Ravignani, $\mathrm{n}^{\circ}$ 34, Buenos Aires, enero 2012.

13 Oscar Chamosa. Lúbolos..., Op. Cit., p. 115.

14 Una transformación similar sucedió a fines del siglo XIX con el carnaval uruguayo. Ver un estudio exhaustivo en: Milita Alfaro. Carnaval. Una historia social de Montevideo desde la perspectiva de la fiesta, "El Carnaval heroico" (1800- 1872), Montevideo, Ediciones Trilce, 1991.
} 


\section{Erica Cubilla}

necesariamente reflejada en los corsos". ${ }^{15}$ Cabe preguntarse, en consecuencia, ¿Cómo se produjo este proceso? ¿Fue necesariamente así? ¿Cómo se expresaban esas diferencias y jerarquías en los carnavales de la ciudad?

En el cambio del siglo XIX al XX, según afirma Leandro Losada, el carnaval se convirtió en un evento que propició la diferenciación social, una arena en que la alta sociedad porteña expresó y afianzó sus modos de distinción y se constituyó como clase aristocrática. A partir de 1884, los bailes organizados en el Club El Progreso estuvieron dotados de un mayor control en la admisión y los sectores más encumbrados dejaron de participar en los festejos oficiales y se recluyeron en espacios más alejados de la ciudad como San Isidro, Tigre, Adrogué y, por sobre todo, el destino de mayor atractivo comenzó a ser Mar del Plata. ${ }^{16}$ Paralelamente, también los carnavales se consolidaron como un festejo de relevancia para los sectores proletarios. En un estudio en curso, Laura Caruso examina los vínculos entre la protesta portuaria de 1904 y dichas fiestas, poniendo el foco en "las formas de organización, despliegue, vínculos y sentidos del carnaval portuario". Esto le permite explorar estas celebraciones como un "factor de disputa por la calle, por el espacio y sus sentidos, con las autoridades". ${ }^{17}$

Ya entrado el siglo XX, uno de los momentos de mayor esplendor de estas celebraciones se produjo en el marco del centenario de la Revolución de Mayo. En los festejos oficiales de carnaval en la Avenida de Mayo, desfilaron un gran número de personas disfrazadas, sociedades, coros, orquestas, carruajes y grupos gauchescos. ${ }^{18}$ Durante la década de 1920 la fiesta oficial siguió desplegándose en el centro porteño. Lo que nos interesa resaltar aquí es que a partir de estos años se desarrollaron con mayor intensidad los diferentes corsos vecinales. Al respecto, Francis Korn documenta sucintamente las características de los carnavales de La Boca, Mataderos, Vélez Sarsfield y Villa Urquiza. Según afirma la autora, se realizó un gran número de corsos y el público concurría desde las primeras horas de la tarde recorriendo las calles en todas direcciones. ${ }^{19}$

El éxito y el arraigo de estas fiestas en la sociedad porteña permiten explicar la reacción de los sectores de izquierda que atacaron directamente a dichos festejos. Los anarquistas, por ejemplo, consideraban que esta diversión popular era una fiesta liberada “del peso de la razón, que paralizaba el sentido de la lógica, anulaba

\footnotetext{
15 Oscar Chamosa, Lúbolos..., Op. Cit., p. 132. Sobre el proceso de expansión urbana de la Ciudad de Buenos Aires: Adrián Gorelik. La grilla y el parque. Espacio público y cultura urbana en Buenos Aires, 1887-1936. Bernal, Editorial de la Universidad Nacional de Quilmes, 1998. James Scobie. Buenos Aires. Del centro a los barrios 1870-1910. Buenos Aires, Ediciones Solar/ Hachette, 1974.

${ }^{16}$ Leandro Losada. La alta sociedad en la Buenos Aires de la "Belle Epoque". Buenos Aires, Siglo XXI Editores, 2008, p. 232-235.

${ }^{17}$ Laura Caruso, "Carnavales proletarios: la huelga grande del Riachuelo y el carnaval al sur de la ciudad, Buenos Aires 1903-1904", ponencia presentada en el IV Taller Historia Social, Género y Derechos, Instituto Interdisciplinario de Estudios de Género, Buenos Aires, 2017.

${ }^{18}$ Micol Seigel. "Cocoliche's Romp: Fun with Nationalism at Argentina's Carnival". The Drama Review, Vol. 44, no2, 2000, pp. 56-83.

${ }^{19}$ Francis Korn. Buenos Aires: los huéspedes del 20. Buenos Aires, Sudamericana, 1974. En especial, capítulo V: "El Carnaval”, p. 205.
} 


\section{Buenos Aires en carnaval: los corsos del barrio de Villa Devoto en la década de 1930}

la facultad reflexiva del individuo y el sentido moral". ${ }^{20}$ Otras corrientes, por ejemplo los comunistas emprendieron "una lucha anti carnavalesca", ya que estos diferenciaban la cultura obrera de la cultura popular. ${ }^{21}$ Para contrarrestarlo, les propusieron a los trabajadores otro tipo de reuniones, celebraciones y festivales propios.

En la década de 1930, el gobierno municipal avanzó en la reglamentación de estas festividades populares. Implementó como medida obligatoria que una comisión vecinal compuesta por asociaciones y habitantes de los barrios interesados en celebrar corsos solicitaran a través de un petitorio la autorización de la Municipalidad para llevarlo a cabo. Según las memorias municipales, por ejemplo, en 1935 “... [El carnaval] se celebró durante los días 3, 4, 5, 9 y 10 de marzo. Fueron autorizados los siguientes corsos, sujetos a las disposiciones del Decreto respectivo: Oficial, Flores (1), Belgrano (2), Boca (3), Villa Devoto (4), Mataderos (5) y Parque de los Patricios (6)". ${ }^{22}$ De modo que la ciudad contó con siete corsos en total: uno oficial y los otros seis en los mencionados barrios:

\section{Mapa 1: Corsos aprobados por la Municipalidad para 1935}

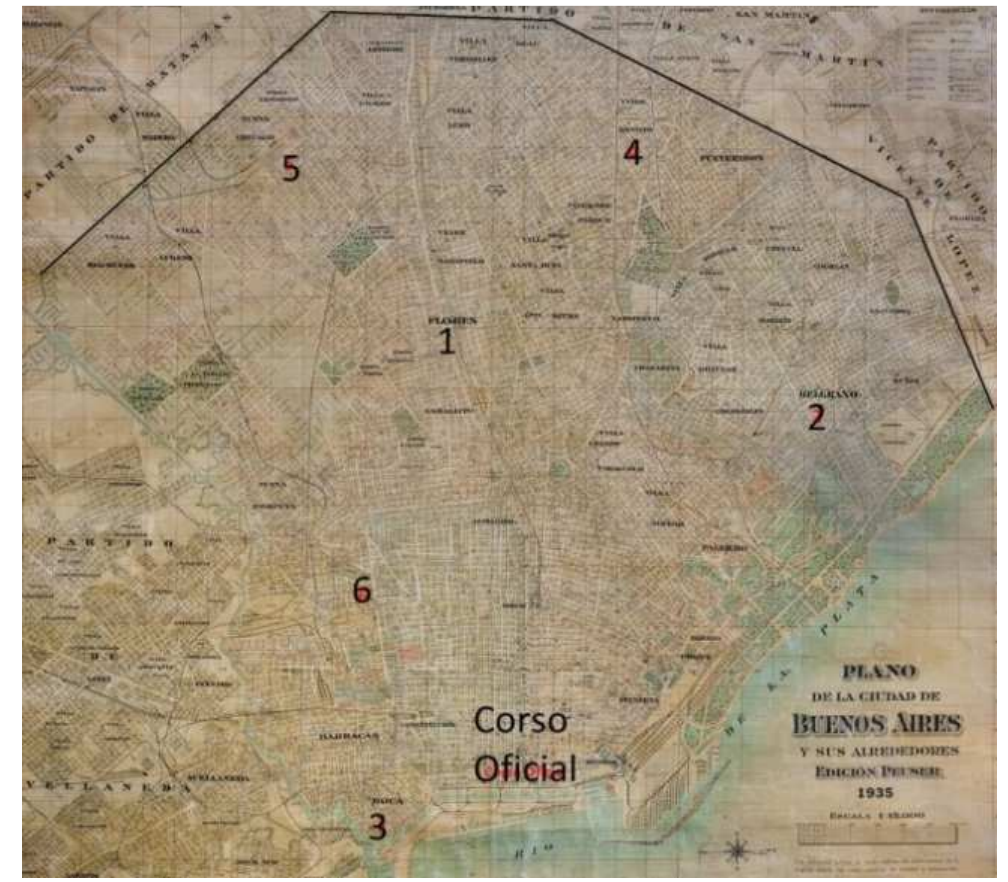

Fuente: Elaboración propia, a partir de Plano de la Ciudad de Buenos Aires y sus alrededores, Edición Peuser, 1935.

Disponible en: <http://trapalanda.bn.gov.ar:8080/jspui/handle/123456789/2303>. [Consulta: 3003-2017]

\footnotetext{
${ }^{20}$ Juan Suriano. Anarquistas. Cultura y política libertaria en Buenos Aires, 1890-1910. Buenos Aires, Manantial, 2008, p. 154.

${ }^{21}$ Hernán Camarero. A la conquista de la clase obrera. Los comunistas y el mundo del trabajo en la Argentina, 1920-1935. Buenos Aires, Siglo XXI Editora Iberoamericana, 2007, pp. 217-283.

22 Municipalidad de la Ciudad de Buenos Aires. Memoria del Departamento Ejecutivo de la Municipalidad de la Ciudad de Buenos Aires, año 1935, 1936, p. 553.
} 


\section{Erica Cubilla}

Tal como observamos en el mapa cuatro corsos barriales (Flores, Belgrano, Villa Devoto y Mataderos) se celebraban en el territorio que no pertenecía a la Capital Federal antes de 1880 y cuya urbanización se consolidó en los años veinte y treinta. En efecto, entre los carnavales de 1870 que describe 0. Chamosa y la información que nos brindan las memorias municipales para los años treinta, podemos reconocer transformaciones en el desarrollo de dichas celebraciones. Destacamos que no sólo se modificó la manera en que los porteños festejaban y se divertían, sino que luego de la ley de Federalización y más entrados los años veinte y treinta, se descentralizaron los eventos. Dicho de otro modo, no sólo había un corso en el centro (en la Avenida Alvear o la Avenida de Mayo) sino que también los habitantes de algunos de los nuevos barrios podían jactarse de organizar su propio corso. A continuación, indagamos las principales características que adoptaban estos eventos barriales.

\section{El corso vecinal: palcos, disfraces y bailes}

En el caso de Villa Devoto, cada año, a partir de la concesión por parte de la Municipalidad del permiso para efectuar el festejo, todas las reuniones y decisiones tomadas por la comisión de vecinos fueron publicadas en el periódico local Noticias Devotenses (ND). ${ }^{23}$ Ahora bien, ¿en qué consistían los carnavales en la periferia de la ciudad? ¿Quién se ocupaban de organizar los festejos, dónde se realizaban y quienes asistían? Anticipemos aquí que decir carnavales significa fundamentalmente decir corso: disfraces, desfiles de carrozas y presentación de palcos. Pero, como demostraremos en este apartado, en Villa Devoto también suponían fiestas, en especial bailes en clubes, cines y residencias particulares.

Semanas antes del inicio de las celebraciones, $N D$ informaba sobre los pormenores de la organización. La prensa local detalló la estructura y la disposición de las actividades. Por ejemplo, la distribución de las guirnaldas que iluminarían el desfile, el valor de los palcos en las diferentes ubicaciones, las vías de acceso de los automóviles y los precios fijados para los mismos, los premios que se entregarían a los ganadores y los jurados para cada categoría. ${ }^{24}$ Los festejos se realizaban en torno a la Plaza General Arenales, principal espacio verde del barrio y el recorrido señalado en el siguiente mapa- comprendía las calles marcadas con línea punteada:

\footnotetext{
${ }^{23}$ Ver por ejemplo: "Mañana darán comienzo las reuniones de corso de carnaval. Prometen alcanzar gran brillo los desfiles a realizarse los días 3, 4, 5, 9 y 10 del corriente", "Concurso de máscaras infantiles", "Quedó constituida una Comisión Auxiliar de Damas" ND, 21/2/1935, p. 3; "Comenzará mañana el corso de Villa Devoto" $N D, 6 / 2 / 1937$, p. 2; "Se constituyó la Comisión de Corso para el próximo carnaval" $N D, 5 / 2 / 1938$, p. 1.

${ }^{24}$ Por ejemplo: "Palcos: 3 primeros premios y 6 segundos premios; carruajes: 2 primeros premios y 4 segundos premios; orfeones: $1 \mathrm{er}$ premio $\$ 100$ y medalla de oro, 2 do premio $\$ 60$ y medalla de plata; 3er premio $\$ 30$ y medalla de plata; grupos humorísticos: primer premio $\$ 50$ y medalla de oro; 2 do premio $\$ 25$ y medalla de plata, 3er premio medalla de plata; grupos gauchescos: primer premio $\$ 50$ y medalla de oro; 2 do premio $\$ 25$ y medalla de plata, 3er premio medalla de plata; mascaras sueltas: 1 er premio medalla de oro, 2do premio medalla de plata" $N D, 25 / 2 / 1933$, p. 3.
} 


\section{Buenos Aires en carnaval: los corsos del barrio de Villa Devoto en la década de 1930}

Nueva York (de Esperanza a Mercedes); Av. Fernández de Enciso (de Nueva York a Asunción), Mercedes (de Nueva York a Pareja) y Bahía Blanca (de Nueva York a Pareja). De ser necesario por el exceso de vehículos se extendía el recorrido a las calles marcadas con una línea doble: Pareja (de Mercedes a Bahía Blanca) y Nueva York (de San Nicolás a Esperanza). El palco oficial, en el cual se situaba la comisión organizadora del corso, estaba ubicado en la calle Nueva York sobre la Plaza Arenales de frente a la calle Chivilcoy:

Mapa 2: Recorrido del Corso Vecinal de Villa Devoto

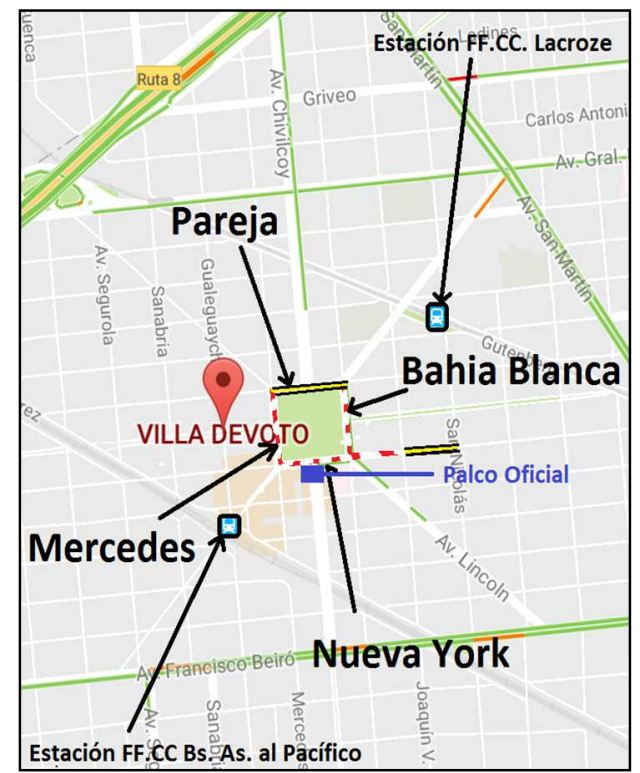

Fuente: Elaboración propia a partir de la información publicada en $N D$ en los meses de enero, febrero y marzo de 1933, 1935, 1938.

Sobre Nueva York se encontraban los palcos preferenciales cuyo precio era más elevado que los situados en las otras calles del recorrido. En cuadro 1 sintetizamos

los distintos precios para los carnavales de 1933, 1935, 1938 y 1939, y los comparamos con el importe de las entradas de cine del barrio. En el caso de los palcos el valor indica el abono de cinco noches por familia y para los vehículos el valor se establece por noche:

Tabla 1: Precios de entradas al corso vecinal

\begin{tabular}{|c|c|c|c|c|c|c|}
\hline $\begin{array}{c}\text { Año/ } \\
\text { precio }\end{array}$ & $\begin{array}{c}\text { Palco } \\
\text { preferencial }\end{array}$ & Palco & Auto & $\begin{array}{c}\text { Chata- } \\
\text { camión }\end{array}$ & Carruaje & Entrada de cine \\
\hline $\mathbf{1 9 3 3}$ & $\$ 25$ & $\$ 20$ & $\$ 4$ & $\$ 10$ & $\$ 25$ & Cine Devoto: 0,40 \\
\hline $\mathbf{1 9 3 5}$ & $\$ 20$ & $\$ 15$ & $\$ 4$ & $\$ 5$ & $\$ 3$ & $\begin{array}{c}\text { Cine Gran Bijou } \$ 0.80 \\
\text { Cine Hollywood } \$ 0.40- \\
0.60\end{array}$ \\
\hline $\mathbf{1 9 3 8}$ & $\$ 20$ & $\$ 15$ & & & & $\begin{array}{c}\text { Cine Teatro Gran Bijou } \\
\$ 0.40\end{array}$ \\
\hline $\mathbf{1 9 3 9}$ & & $\$ 15$ & gratis & & & $\begin{array}{c}\text { Cine Teatro Gran Bijou } \\
\$ 0.40\end{array}$ \\
\hline
\end{tabular}




\section{Erica Cubilla}

Fuente: Elaboración propia a partir de los datos publicados en $N D$ en los meses de enero, febrero y marzo de 1933, 1935, 1938 y 1939.

Como podemos apreciar, la participación en los corsos vecinales implicaba una inversión de dinero significativa. Aun teniendo en cuenta que los abonos de los palcos eran por familia, en 1933 el valor equivalía a un total de 62 entradas de cine, en 1935 a unas 25 entradas y en 1938 a unas 37. La información recabada no hace referencia a la cantidad de personas que podían ocupar un palco, pues efectivamente, al aumentar el número de participantes disminuía el costo por persona. Empero, es importante destacar que los gastos de estos festejos no arraigaban únicamente en las entradas, ya sea de palcos o de vehículos, sino que también debe tenerse en cuenta la utilización de disfraces, máscaras, el material necesario para caracterizar y adornar el palco o vehículo y el cotillón típico de estas celebraciones. El coste se incrementaba si además se concurría a los bailes de los clubes cuyas entradas iban de \$1 a \$3 por persona. En efecto, participar de los carnavales requería de una economía familiar relativamente holgada que permitiera gastar estas sumas de dinero en una actividad de entretenimiento.

Las fiestas se desplegaban durante cuatro noches, por lo general a partir de las 20 hs. y se extendían hasta entrada la madrugada. Allí las familias festejaban con humor y realizaban juegos con serpentina, papel picado y flores naturales. Así lo describía el periódico barrial para los festejos del 26, 27 y 28 de febrero de 1933: "Fue su recorrido el escenario de una espléndida fiesta de la población, alegre y cordial, que bajo guirnaldas luminosas afirmaba su derecho a la sana y necesaria expansión". ${ }^{25}$ Una banda musicalizaba la velada: "Instalada en un palco en las calles Nueva York y Mercedes, el conjunto de la Sociedad Operai Italiani que dirige el maestro Barbieri, interpretó un variado programa musical, seguido con visible interés por el público."26

Como ya mencionamos, existían diferentes maneras de participar del corso. Las familias podían alquilar un palco o desfilar con sus autos o carruajes. ${ }^{27}$ Las fotografías publicadas en $N D$ nos muestran a las jóvenes disfrazadas presentando sus palcos adornados con diferentes motivos, entre otros: castillos encantados, gitanas españolas, guerreras griegas, damas de corazones, aldeanas rusas, muñecas "Lenci", tal como vemos en la siguiente imagen:

\footnotetext{
${ }^{25} N D, 4 / 3 / 1933$, p. 3.

26 Ibídem.

27 Por ejemplo, en 1935 los palcos que resaltaba ND fueron: "Cariocas 1935", "Muñecas Lenci", "Fantasía de Dandy", "Escolares 1935", "Chicas de Hollywood”; en 1937 las familias adornaron sus palcos de: "Mandarines chinos", "Damas Victorianas", "Muñecas Lenci", "Paisanas rusas", "Fantasía española", "Aldeanas españolas"; para 1938 la prensa destacó los palcos de: "Casanova fantasía", "Aldeanas tirolesas", "Caperucitas rojas", entre otros motivos.
} 


\section{Buenos Aires en carnaval: los corsos del barrio de Villa Devoto en la década de 1930}

Imagen 1: "Muñecas Lenci"

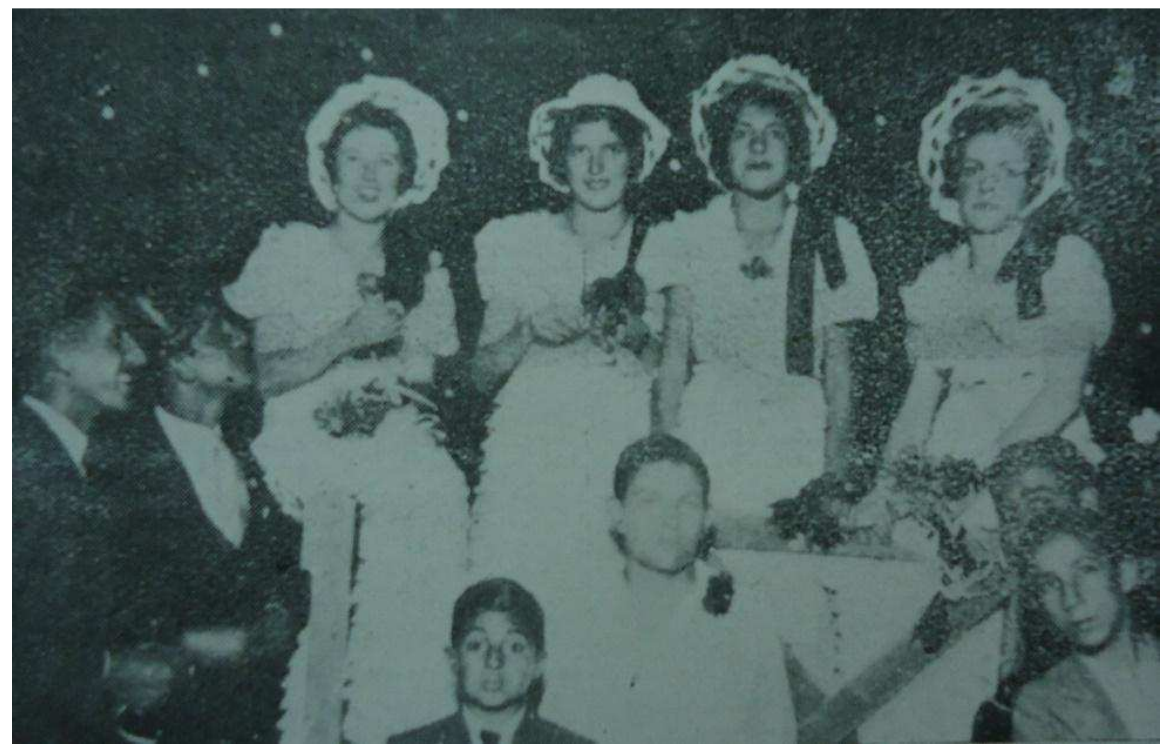

Fuente: $N D, 9 / 3 / 1935$, p. 4 .

Las fotos publicadas en la prensa local nos ofrecen algunas pistas para responder quiénes participaban del corso vecinal. En su mayoría, las imágenes de $N D$ exponían a los distintos grupos en los palcos, mientras que fueron casi nulas las fotografías del desfile de carruajes o del público. Al examinarlas, se destaca la fuerte presencia femenina en los palcos, en menor medida la presencia de niños y la casi nula aparición de hombres. Por ejemplo, la imagen 2 es la única fotografía que relevamos con presencia netamente masculina:

Imagen 2: "Los piratas de la muerte”

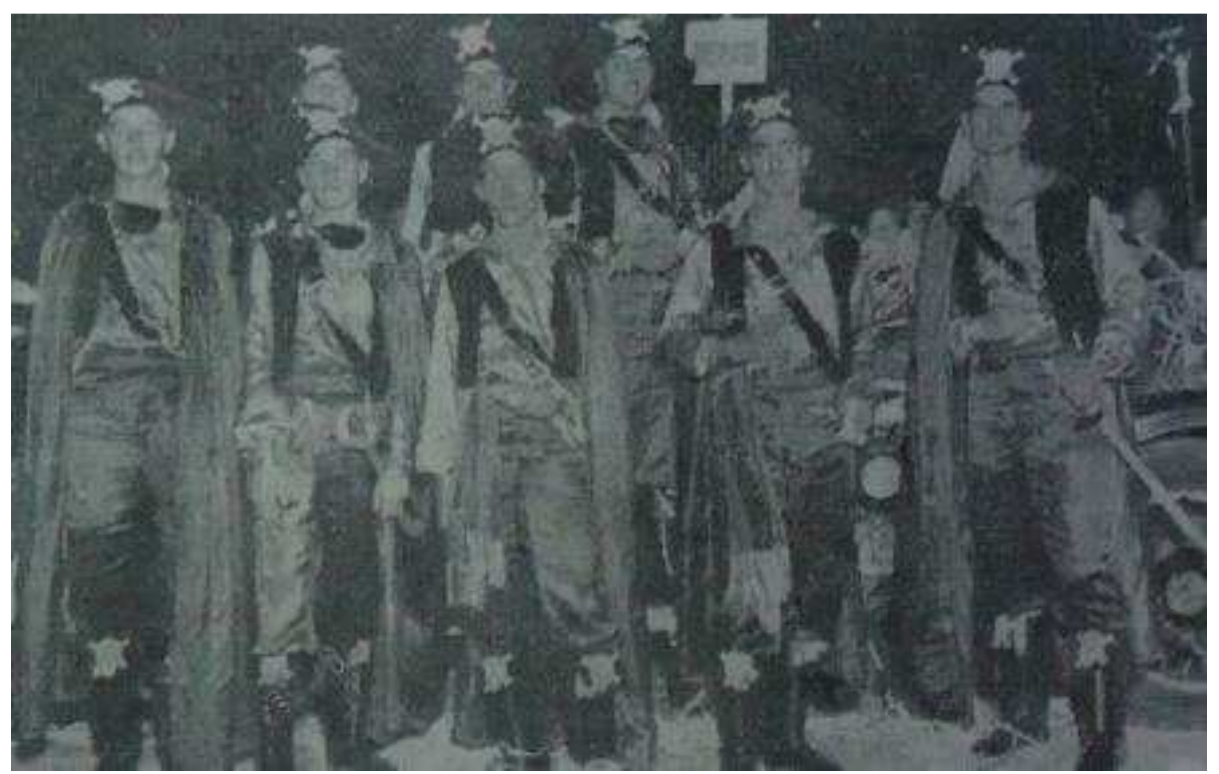

Fuente: $N D, 27 / 2 / 1937$, p. 3.

Estos retratos nos permiten inferir que la participación más activa en los palcos y carruajes en cuanto a disfraces y caracterizaciones era femenina. Es decir, 


\section{Erica Cubilla}

aunque $N D$ publicaba la nómina de familias que habían alquilado un palco y la temática con la que se habían caracterizado, las fotografías publicadas aluden mayormente a jóvenes señoritas. Para retratar estos eventos, la cámara se centra en la figura femenina, mientras que las fotos de hombres disfrazados no predominan. Notablemente, el rol de las mujeres se volvía central en una celebración pública cuya principal cualidad era el juego de caracterizaciones e "identidades prestadas."28

Otras familias que mostraban sus atuendos desde sus autos y carruajes circulaban por las calles demarcadas previamente. Entre sus disfraces la prensa local destacaba: gitanas rusas, marineros, piratas, que se sumaban al desfile de orfeones, murgas y centros gauchescos. El periódico local informó la presencia de agrupaciones que se reiteraban año a año: "Los riojanos”, “As de espadas”, “Juventud primaveral", "Los baquianos de La Pampa", "Cómo se canta en Nápoles", "Los microbios", "Los eléctricos", "Los revoltosos". Aquí es importante resaltar que, a diferencia de las imágenes que indicamos anteriormente, no aparecían en $N D$ fotografías de las murgas, orfeones y centros gauchescos desfilando. Cabe mencionar que se podía participar del corso sin contar con palco o vehículo adornado. Algunas familias observaban los desfiles desde las veredas de las calles que conformaban ese circuito principal. Al finalizar las jornadas de fiesta, se seleccionaban y premiaban las mejores bandas musicales, carruajes, palcos, grupos humorísticos y máscaras. Posteriormente, $N D$ publicaba la lista de ganadores y fotografías alusivas.

Durante los dos o tres fines de semana en los que se desarrollaba el evento, los comercios, por ejemplo las librerías, no estaban ajenos al carnaval e incluso se veían beneficiados por los festejos. Así, en las mismas páginas donde se leía información sobre los corsos, se podía encontrar: "Librería, imprenta y despacho de revistas y diarios. Serpentinas y artículos de carnaval. Artículos para colegios, comisiones, servicio mensajero. Obsequios variados a los niños. Selección, gusto. Precios moderados." 29

Como hemos señalado, decir carnaval significaba decir corso vecinal pero también bailes. Los clubes aprovechaban para recaudar fondos realizando diversas actividades, se efectuaban también festejos en algunos cines e inclusive en casas particulares. ${ }^{30}$ En el caso de las fiestas organizadas en clubes o cines, en ocasiones encontramos la información publicada en el periódico local, y a posteriori, una crónica sobre las reuniones realizadas y sus respectivas fotografías. ${ }^{31}$ Las

\footnotetext{
${ }^{28}$ Bisso, Andrés. El de gaucho..., Op. Cit., p. 104.

${ }^{29} \mathrm{ND}, 4-3-1933$. El subrayado es nuestro.

30 "Notas del Club Villa del Parque. Las fiestas de carnaval"; "Fiestas de disfraces" "Concurso para niños" $N D, 25 / 2 / 1933$, p. 5; "Baile de disfraz y fantasía del Club Villa Devoto" ND, 25/2/1935, p. 4; "Bailarán en la Asociación de Fomento de Villa Devoto Oeste. Han anunciado siete bailes de disfraz y fantasía" ND, 6/2/1937, p. 3.

31 Vale recordar aquí que, durante la década de 1930, varios eran los cines que funcionaban en Villa Devoto y que servían también como salones para estos bailes. A través de las publicidades en la prensa barrial y del relato en las memorias de Fortunato Troisi hemos podido relevar la existencia de 7 cines, cuatro de ellos denominados "cine teatro". Generalmente, publicaban sus carteleras en los periódicos locales y describían allí las distintas funciones, películas y costos de las entradas, estas
} 


\section{Buenos Aires en carnaval: los corsos del barrio de Villa Devoto en la década de 1930}

invitaciones versaban: "Olimpia Lawn Tennis Club. Gran baile de disfraz y concurso de máscaras"; "Club Villa Devoto. Baile de disfraz y fantasía"; "Club Social Estudiantes. Con 4 grandes bailes celebrará las fiestas de carnaval"32; "Cine Hollywood. Carnaval 1935", "Cine Gran Bijou. Grandes concursos carnavalescos", "Bailes en el Cine Devoto".33 Posteriormente, las descripciones de estas fiestas resaltaban la concurrencia, la alegría de los presentes y el desarrollo de bailes hasta altas horas de la madrugada. Así relataba, por ejemplo, $N D$ la fiesta realizada los días 11, 12 y 13 de febrero de 1933 en el Club Social Estudiantes de la calle Fernández de Enciso 396: "En la amplia terraza tuvieron lugar los grandes bailes anunciados por las autoridades con objeto de festejar las fiestas de carnaval. Una crecida concurrencia asistió a las fiestas mencionadas en las que al compás de una orquesta se bailó animadamente hasta avanzada la madrugada". ${ }^{34}$ Del mismo modo, informaba sobre un encuentro en el Club Devoto en febrero de 1934: "Extraordinario lucimiento alcanzaron los recibos de máscaras realizados en esta entidad. El local del Club, que había sido objeto de un llamativo arreglo e iluminación, se vio concurrido por numerosas familias, manteniéndose las reuniones en animado baile hasta bien entrada la madrugada". ${ }^{35}$ A esta reseña sobre la fiesta, se le sumaba la siguiente imagen:

Imagen 3: "Baile de carnaval en el Club Devoto"

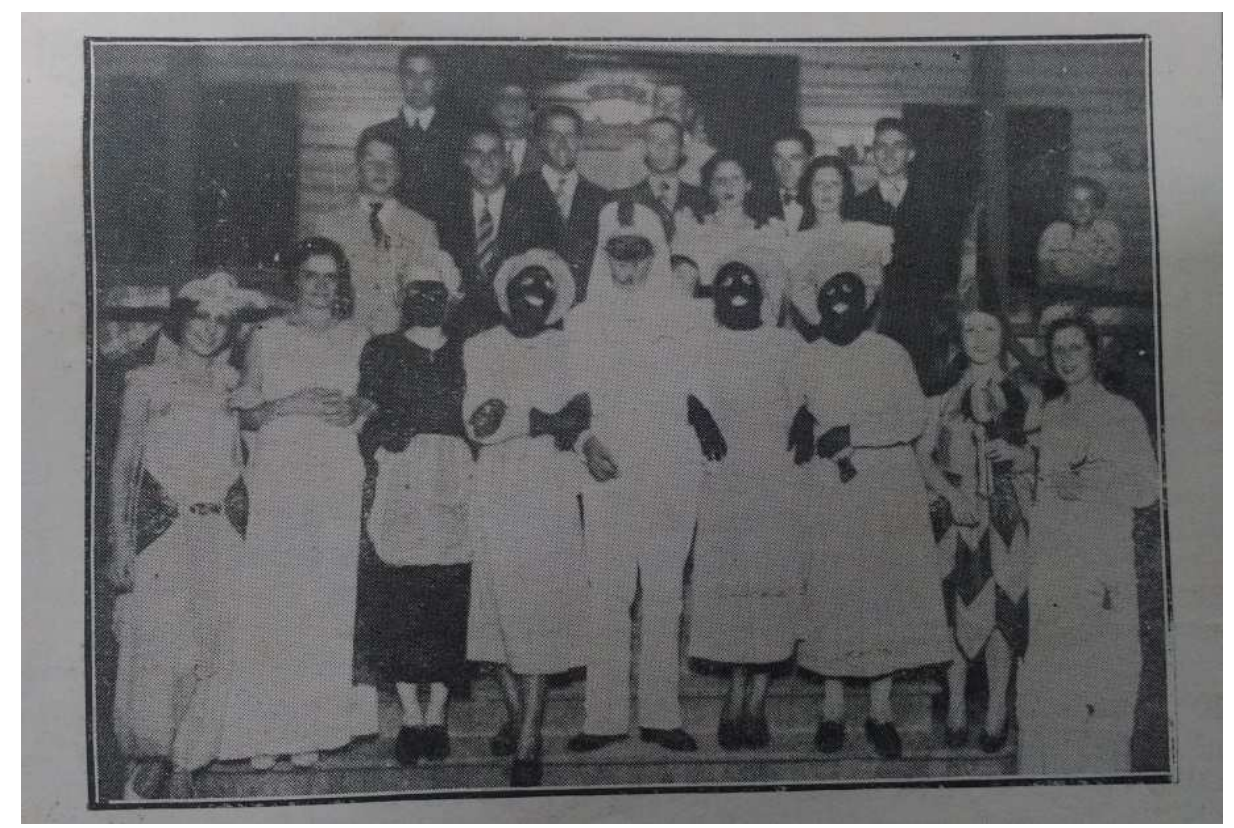

oscilaban entre 0,20 y 0,80 centavos. Asimismo, las salas que funcionaban también como teatro publicitaban las obras de diferentes compañías, las entradas variaban entre 1 y 5 pesos. Evidentemente, sus empresarios también aprovechaban los carnavales para organizar festejos y sumarse a la oferta de entretenimientos de esas noches de verano. Ver: Fortunato Nicolás Troisi. $L a$ villa Devoto que vi crecer. CABA, Edición del autor, 1979. Fortunato Nicolás Troisi. La villa Devoto que vi crecer (segunda parte). CABA, Edición del autor, 1988.

$32 N D, 25 / 2 / 1933$, p. 4

${ }^{33} N D, 25 / 2 / 1935$, p. 8

${ }^{34} N D, 4 / 3 / 1933$, p. 1.

$35 N D, 17 / 2 / 1934$, p. 4. 


\section{Erica Cubilla}

Fuente: $N D, 17 / 2 / 1934$, p. 5.

Por último, notemos brevemente las reuniones que se llevaban a cabo en los hogares de los habitantes de Villa Devoto con motivo de festejar el carnaval. Precisamente, el periódico local publicaba crónicas, describiendo estos encuentros, detallando el nombre de los presentes y documentándolos con alguna foto. Así informaba $N D$ sobre un "asalto de máscaras" en 1933:

El asalto de máscaras que se realizó el domingo pasado a la terminación del corso local en la residencia que el señor Bernardino Devicente posee en la localidad, motivó una lucida reunión donde la nota sobresaliente la constituyó la gran alegría de que hicieron derroche los asistentes. Fue una bonita fiesta en la que la animación no decayó un solo instante hasta avanzada la madrugada. Anotamos presentes a las familias de: Ammar, Almeyda, Maspollet, González Santos, Baso, Chaumont, Aramo, Campos, Couto, Santos, Morales, Porta, Bacarrere, Callejas, Ivaldi. ${ }^{36}$

De igual modo, el 13 de febrero de 1937 el semanario destacó la realización de diversos "asaltos de máscaras" en casas particulares: "fue 'asaltada' la casa del señor Ricardo Bertrán por un grupo de máscaras, bailándose animadamente hasta las primeras horas de la madrugada del día siguiente." 37 Estos ejemplos nos hablan, por un lado, de la existencia de diversas maneras de celebrar sin estar necesariamente incluidas en los eventos oficiales y abiertos a toda la comunidad, y por otro, de la relevancia que adquirían los diferentes círculos de amistades entre los residentes de Villa Devoto y sus familias.

En su conjunto, el corso oficial en la Plaza Arenales, los festejos en clubes, cines-teatros o residencias familiares demuestran la vivacidad y plasticidad del carnaval y también los diversos actores involucrados en su organización y participación. Existía una fiesta oficial, organizada por las instituciones vecinales y vecinos destacados que incluían disfraces, desfiles y presentación de palcos, carruajes y agrupaciones artísticas en la plaza y coexistía con otras tantas celebraciones en diferentes instituciones como clubes y sociedades de fomento, entre ellos, el Club Devoto, el Olimpia Lawn Tennis Club, el Cine Hollywood y en residencias particulares. A continuación, exploramos los procedimientos y reglamentaciones que mediaban entre el deseo de organizar un corso vecinal y su ejecución.

\section{Las asociaciones y los vecinos ante la regulación municipal}

Como hemos referido, la década de 1930 signada por el Golpe Militar y marcada por la Restauración Conservadora, impactó sobre los usos del tiempo libre de la sociedad argentina, en general y porteña, en particular. El gobierno municipal

\footnotetext{
${ }^{36} N D, 4 / 3 / 1933$, p. 5.

${ }^{37} N D, 13 / 2 / 1937$, p. 4.
} 


\section{Buenos Aires en carnaval: los corsos del barrio de Villa Devoto en la década de 1930}

avanzó en la reglamentación de las festividades populares. Durante su intendencia, Mariano de Vedia y Mitre conformó en 1933 la Comisión Permanente de Fiestas Populares (CPFP). Los empleados municipales encargados de esta comisión tenían como objetivo principal estimular pero también controlar las diversas conmemoraciones desarrolladas en el ámbito de la Capital Federal. Según las memorias municipales, sus tareas radicaban en:

...organizar y dirigir los festejos populares en las distintas oportunidades determinadas por el calendario, también en ocasiones extraordinarias, está a cargo de esta comisión, que también interviene en la prestación de elementos de propiedad de la Comuna, solicitados para fiestas organizadas por entidades oficiales o particulares, ejerciendo un eficiente control con el objeto de evitar pérdidas o deterioro. ${ }^{38}$

De esta manera, la Municipalidad con la creación de CPFP se arrogaba el control y la organización de las diferentes "Fiestas Populares". En particular, respecto al carnaval, las autoridades dispusieron un protocolo a seguir. Este establecía que cada barrio que deseara efectuar corsos debía solicitar a través de una comisión de vecinos y asociaciones, una autorización de la CPFP.

En el caso de Villa Devoto, los sistemáticos intentos de la Municipalidad por reglamentar los carnavales barriales a través de la CPFP y de la policía de la Capital Federal, generaron descontento entre los vecinos. En 1933, ND se hacía eco de esta insatisfacción, explicando que:

La CPFP había dispuesto en un principio la no realización del corso vecinal en nuestra localidad, decisión esta que fue posteriormente modificada ante las gestiones de la Compañía de Boys Scouts General Arenales. Ante estas gestiones la mencionada comisión, transó en la realización del corso, pero estas reuniones quedaban subordinadas a condiciones tan curiosas como irritantes: La Municipalidad no aportará ni con el más insignificante material para su realización; toda la ganancia que se produzca se destinará a la Asistencia Pública Central; en caso de que arroje pérdidas, estas correrán por cuenta de la comisión organizadora. ${ }^{39}$

Este fastidio se relacionaba, por un lado, con la negativa para la realización del corso vecinal, y por el otro, luego de conseguir la autorización se criticaba la utilización de los fondos recaudados a discreción del gobierno municipal. Este descontento con respecto al uso del dinero demostraba, creemos, cierto sentimiento de pertenencia. En efecto, la comisión organizadora del evento reclamaba que las ganancias sean invertidas únicamente en Villa Devoto.

Tal era la centralidad de esta festividad, que a inicios de 1933 una comisión de vecinos junto a la Compañía de Boys Scouts “General Arenales" realizó un

38 MDEMCBA de 1933 y 1934, 1935, p. 490.

${ }^{39} N D, 25 / 2 / 1933$, p. 1. 


\section{Erica Cubilla}

petitorio a la Municipalidad para emprender el "Corso Vecinal de Villa Devoto" sin injerencia de la CPFP. La respuesta fue positiva, según lo publicado en $N D$ :

Tal como lo pedíamos, nuestro próximo corso estará organizado por una comisión de caracterizados vecinos y su producto no emigrará de Devoto. Conseguidos tales anhelos, es de esperar ahora, que el vecindario e instituciones locales, a estas últimas especialmente hacemos nuestro llamado, cooperen y secunden a la comisión de vecinos que ha de correr con su organización. ${ }^{40}$

Esta oposición de los vecinos a la intervención municipal puede ser explicada quizás por la larga tradición organizativa de los vecinos de Villa Devoto, quienes celebraban fiestas de carnaval desde 1919 y por la fuerte presencia asociativa en la zona, cuya primera Asociación de Fomento databa de 1896. Asimismo, ND enfatizaba en las particularidades que tendría una fiesta dirigida por una comisión conformada por habitantes del barrio: “[el corso] estará organizado independientemente, vale decir, sin la intervención de las autoridades edilicias, con lo cual se dará a nuestro corso el sello de familiaridad, tan característico de las reuniones organizadas por las comisiones vecinales." 41 Notablemente, la peculiaridad que se le pretendía dar al corso de Villa Devoto era la familiaridad, la cual se traducía en la participación de los vecinos y las asociaciones vecinales en su preparación.

En 1933, la Municipalidad aceptó el pedido, sin embargo esta autorización debía solicitarse año a año ante la CPFP. Es decir, cada barrio que aspiraba a organizar su propio corso por fuera de la celebración oficial en el centro, debía someterse a este trámite. Este protocolo nos revela, primero, la presencia de un grupo de vecinos notables que debía encargase de organizar el evento; en segundo lugar documenta la actitud de oposición y negociación de cara a los mandatos municipales. Por último, no deja duda acerca del interés que algunas asociaciones tenían en el desarrollo y prosperidad del barrio.

Como se observa, las objeciones planteadas tenían como causa principal la insatisfacción por las reglas municipales que afectaban al festejo propiamente dicho. Nos referimos a toda aquella normativa cuyo objetivo radicó en transformar la forma y el contenido tradicional del evento. En primer lugar, $N D$ manifestó su descontento por las desigualdades que la Municipalidad demostraba entre el centro y los demás barrios en la colaboración de la infraestructura para los carnavales:

La posición oficial siempre es cómoda y fácil. Cuando los festejos producen alguna perdida, se desentienden cómodamente, incidiendo aquella sobre el patrimonio particular de los organizadores. Su actitud cambia fundamentalmente cuando los festejos producen una ganancia, por ínfima que sea. (...) la negación

\footnotetext{
${ }^{40} N D, 25 / 2 / 1933$, p. 1.
}

${ }^{41} N D, 14 / 1 / 1933$, p. 2. 


\section{Buenos Aires en carnaval: los corsos del barrio de Villa Devoto en la década de 1930}

de los elementos más indispensables a las comisiones que buscan el apoyo oficial, pone de manifiesto el menguado propósito de sabotear en toda forma el éxito de los corsos vecinales. Todos los esfuerzos, todos los elementos y todas las atenciones se concentran en el corso metropolitano; los corsos vecinales quedan librados a su propia suerte con la pesada carga de la responsabilidad a que antes nos referíamos. ${ }^{42}$

En el ejemplo citado, la queja está directamente relacionada con el nulo interés por parte de la Intendencia. En numerosas oportunidades, el periódico reflexionó acerca de esta falta de apoyo o de sostén político para los corsos vecinales, particularmente el de Villa Devoto. ${ }^{43}$ En este caso, el conflicto entre las comisiones de vecinos encargadas de organizar el carnaval y la Municipalidad estaba generado por la necesidad de cubrir los gastos para financiar el festejo en materia de iluminación, artefactos de sonido, difusión del evento, entre otras.

En segundo lugar, en repetidas oportunidades $N D$ se hizo eco de las prohibiciones y modificaciones que el poder político planteaba a través de la policía de la Capital Federal para las celebraciones del carnaval. ${ }^{44}$ Por ejemplo, cuando en febrero de 1935 había quedado sin efecto el estado de sitio imperante a partir del golpe militar, el periódico local celebró que nuevamente se podrían utilizar máscaras y caretas durante las fiestas. ${ }^{45}$ Una semana después, $N D$ se refirió al edicto policial sobre el uso de esta indumentaria:

\footnotetext{
$42 N D, 19 / 2 / 1938$, p. 1

43 Ver también lo publicado en vísperas del carnaval de 1934: "Los corsos vecinales malogrados por la Intendencia Municipal” ND, 10/2/1934, p. 1. También antes del carnaval de 1935: "Según esta versión, la Intendencia no autorizaría este año la realización de los corsos vecinales, auspiciando únicamente un corso único que se realizaría en la Avenida Alvear. Razones para justificar una lógica protesta no faltarían si se considera el carácter eminentemente popular que entrañan estas fiestas, máxime en los barrios que, como el nuestro, se verían de tal modo privados de uno de los mayores atractivos, con el consiguiente perjuicio para el comercio y vecindario en general" $N D, 2 / 2 / 1935$, p. 1. Algo similar alegó el diario para los carnavales de 1937: “... aparte de la ausencia de todo aliciente en la organización de estos festejos, las comisiones vecinales se ven necesariamente cohibidas ante las serias responsabilidades que sobre ellas pesarían en el hipotético caso de un fracaso en sus gestiones. (...) La intención de sabotear en toda forma a estos corsos surge evidentemente ante la negativa de proveer de elementos a las comisiones que desinteresadamente buscan dar cumplimiento a las misiones que les fueran confiadas" "Todos los esfuerzos oficiales, todos los materiales, todas las atenciones se concentran en el corso de la calle Corrientes; los corsos vecinales quedan huérfanos de toda ayuda" en: $N D, 30 / 1 / 1937$, p.1, haciendo clara referencia a las diferenciaciones que existían entre el centro y los barrios.

${ }^{44}$ En 1934, el periódico informaba: "La jefatura de policía ha dictado un edicto prohibiendo, como en años anteriores, el uso de la careta, antifaces o el uso de pinturas que desfiguren el rostro. Tal disposición, que se dicta en virtud del estado de sitio, contiene una excepción en lo que se refiere a las damas y menores que podrán usar medio antifaz. Asimismo ha sido prohibido el juego con agua y pomos en las calles de la Capital." ND, 10/2/1934, p. 2.

45 "Se permitirá usar careta durante las fiestas de carnaval. Numerosos comerciantes y vecinos nos han solicitado informes sobre la prohibición que rigió en años anteriores sobre el uso de la careta y el antifaz durante las fiestas de carnaval. La prohibición de referencia ha desaparecido con el levantamiento del estado de sitio que rigió en años anteriores exigiéndose cómo único requisito para usar esos adminículos el permiso que conceden las autoridades policiales. Este permiso no es indispensable para menores de catorce años" $N D, 16 / 2 / 1935$, p. 2.
} 


\section{Erica Cubilla}

La Jefatura de Policía sorprende ahora a la población que se aprestaba alegremente a festejar dignamente, con un edicto prohibiendo el uso de la careta durante los días de carnaval. Los festejos de carnaval desde hace cuatro años vienen decayendo notablemente; en gran parte, esa decadencia debe atribuirse a la serie de restricciones y prohibiciones con que se sujeta a tales festejos. (...) La Jefatura de Policía por lo tanto, condena a nuestra población a pasar otro carnaval sin uno de los elementos que más espiritualidad y animación llevaban a esas fiestas. ${ }^{46}$

Como se observa, el periódico objetó la reglamentación de la policía en tanto alteraba el espíritu de los festejos. Años después, en 1938 un nuevo edicto policial interfería en el carnaval porteño y $N D$ volvía a criticar este tipo de disposiciones: "la Intendencia Municipal dictó la semana pasada un decreto por el cual se prohíben durante los próximos festejos de carnaval el uso de disfraces de aspecto trágico o macabro por el temor que infunden en los menores y la inquietud que provocan aun en los mayores." 47 Vemos aquí que los arbitrajes sobre los festejos no se limitaban solamente a cuestiones materiales, de sonido o iluminación, sino que también las normativas influían llamativamente en cómo se llevaba a cabo el carnaval. La Municipalidad y la policía tenían injerencia, o intentaban tenerla, inclusive en los atuendos utilizados. Claro que es materia pendiente el ponderar el grado de acatamiento de esta regulación por parte de quienes participaban en los corsos vecinales. ${ }^{48}$

Por último, queremos subrayar que en los ejemplos seleccionados, a la par de los conflictos con los poderes políticos y sus restricciones, subyace también la reflexión sobre la decadencia del carnaval como fiesta popular. Al respecto, luego de los carnavales de 1938, el periódico local especulaba:

Los que tienen vivo aun el recuerdo de los corsos que se realizaban en nuestra localidad diez o quince años atrás, han sufrido el proceso involuntario de una comparación, con los últimos corsos presenciados en la Plaza Arenales. (...) El hecho observado entre nosotros se repite en otras zonas de la capital. De poco han valido la entrada gratuita para carruajes, la donación de palcos y los mil recursos empleados para reconquistar los prestigios del corso de carnaval. Entre nosotros, la realidad en una y ella es que nuestro corso ha caído en una decadencia tal, que difícilmente volveremos a presenciar los desfiles familiares de sus primeros años. Debemos por ello preguntarnos ¿dejó Devoto de ser un barrio para corso? ${ }^{49}$

${ }^{46} N D, 21 / 2 / 1935$, p. 3. El subrayado es nuestro.

${ }^{47} N D, 26 / 2 / 1938$, p. 1

${ }^{48}$ A. Bisso indaga la aceptación o el rechazo de los edictos policiales prohibitivos por parte de los vecinos observando a través de la prensa sus caracterizaciones en los concursos. En: Andrés Bisso. "¿El de gaucho o el de Tom Mix?... Op. cit.

${ }^{49} N D, 5 / 3 / 1938$, p. 3. 


\section{Buenos Aires en carnaval: los corsos del barrio de Villa Devoto en la década de 1930}

Fuera o no a causa de las restricciones del gobierno conservador, lo cierto es que el carnaval no suscitaba el interés de antaño y esto era una materia de preocupación. Empero, al reparar en la autobiografía de un residente de Villa Devoto, la memoria de esta festividad adquiere un tono más optimista:

Los corsos constituían uno de los hechos más trascendentes que dieron fama a la Plaza Arenales y por extensión a toda Villa Devoto. El primer año que se hicieron fue en 1919, organizados por la Sociedad de Fomento "El Triángulo". El corso comenzaba frente a la estación Villa Devoto con un recorrido total de siete a nueve cuadras 50

Después del corso de la Avenida de Mayo el otro que era muy amplio fue el de Palermo, por las calles de los tradicionales bosques, financiados por fuertes firmas comerciales; los corsos que más brillaron fueron los últimos días de carnaval con corsos de flores; la carroza más bonita era la que más flores granjeaba. Hubo muchos corsos que se armaban en los barrios: los más destacados ya los mencioné, figurando como cuarta estrella el de Villa Devoto51

Como se observa, en la memoria de Fortunato Nicolás Troisi, los festejos mantienen su atractivo y popularidad y merecen integrar el ranking de los corsos de los barrios porteños. Esta imagen, sin desestimar sus sesgos y su afán por edulcorar y engrandecer el pasado local, documenta -al igual que las otras múltiples evidencias reunidas aquí- la centralidad del carnaval en los barrios porteños en los años treinta. No sorprende entonces que la Plaza Arenales haya sido el escenario elegido por A. Bioy Casares para iniciar la aventura de Emilio Gauna en el verano de 1930.

Al parecer, esa década del treinta marcaría el punto de máximo apogeo del carnaval en los barrios, momento a partir del cual se iniciaría un lento declive. Así, por ejemplo, el 7 de enero de 1939 ND publicaba una nota que hubiera sido difícil de imaginar diez años antes. En su portada, formuló lo que parecía una pregunta retórica: ¿Deben realizarse nuevos corsos de carnaval en Devoto? A decir verdad, se trataba de una encuesta abierta. Pero la novedad era que no pocos vecinos respondían negativamente. Su desaprobación se fundaba en varios motivos. Argumentaban que los corsos habían perdido su atracción, pues no suscitaban el entusiasmo de los habitantes del lugar. También señalaban que se trataba de un esfuerzo desmesurado pues no se contaba con la colaboración de la Municipalidad. El Dr. Francisco Guma (Presidente de la comisión vecinal de 1935) afirmaba: "Devoto ha modificado indudablemente su estructura social. Las principales familias se retraen de estos actos populares, buscando ambientes más propicios a sus nuevas costumbres. De ahí su ausencia reiterada en los últimos corsos realizados". 52 En un contexto en el que se extendían el acceso a los viajes por vacaciones y se

\footnotetext{
50 Fortunato Nicolás Troisi. La villa Devoto... Op. Cit., 1979, p. 102.

${ }^{51}$ Fortunato Nicolás Troisi. La villa Devoto... Op. Cit, 1988, P. 235.

${ }^{52} N D, 14 / 1 / 1939$, p. 1.
} 


\section{Erica Cubilla}

multiplicaban los bailes en clubes y salones, no sorprende que mermara la participación de las familias en estos festejos veraniegos. Quizás buscando atraer a otras familias es que los corsos de 1939 se trasladaron a otro sector de Villa Devoto y su recorrido se extendía al sur de la Estación Devoto del F.C.B.A.P., comprendía la Av. Tres Cruces entre Chivilcoy y Segurola a unas 7 cuadras de la Plaza Gral. Arenales.

Por lo aquí analizado, esa pérdida de vitalidad pareciera poder atribuirse al impacto negativo del control municipal, al menos a los ojos de algunos de los actores involucrados, aunque también, creemos, que cabe inscribir este declive del carnaval en un marco más amplio de transformaciones sociales y culturales, en particular referidos a los usos sociales del tiempo libre en la segunda posguerra.

\section{Consideraciones finales}

Para los años treinta el barrio era un escenario fundamental para celebrar y disfrutar el carnaval. Podría decirse que, en esos años, cristalizó una segmentación entre el centro y los barrios en términos de infraestructura, acceso a las actividades culturales y posicionamiento económico. Estas diferenciaciones también se vieron expresadas en las fiestas pues el barrio se convirtió en un espacio de entretenimiento alternativo al del centro de la ciudad.

Como documentamos, el carnaval se podía celebrar de diversas maneras. La realización de los corsos vecinales requería de una organización planificada consignada a hombres destacados de Villa Devoto y exigía la participación de distintas entidades barriales y familias reconocidas. Estas celebraciones se desarrollaban en un marco familiar, ordenado y sin ostentaciones. Los palcos, la principal atracción, mostraban a mujeres y niños disfrazados. Al mismo tiempo, se llevaban a cabo bailes en clubes, cines y en residencias particulares que aumentaban año a año su concurrencia.

Organizar y festejar los carnavales suponía ponerse en relación con el poder municipal, una relación que a juzgar por las evidencias recogidas fue de tensión. Evidentemente organizar un corso costaba dinero y podía convertirse en un buen negocio para las arcas municipales y el comercio local, pero también presuponía riesgos. A los ojos de la comisión vecinal de Villa Devoto, la Municipalidad era poco generosa en su apoyo a los corsos barriales y dejaba que la aventura de la inversión descansara en otros hombros y no en los propios. Por eso, encontramos quejas recurrentes sobre el favoritismo de las autoridades para con el corso oficial en "el centro" y la marginación de "los barrios".

En tal sentido, festejos, como los carnavales, nos ofrecen un punto de mira para comprender la dinámica de las relaciones -en ocasiones conflictivas- entre la sociedad civil, las asociaciones y el Estado municipal. En este caso, hemos podido desentrañar las disputas que surgieron en la década de 1930 en el proceso de realización de unos festejos cuyo principal objetivo debía ser la distensión, la diversión. Por tanto, podemos decir que, de manera similar al caso bonaerense, los 


\section{Buenos Aires en carnaval: los corsos del barrio de Villa Devoto en la década de 1930}

carnavales de Villa Devoto funcionaron como instancia de negociación entre los distintos actores mencionados, y que fueron durante los años treinta el resultado de una puja constante entre el gobierno y la acción vecinal. El botín disputado incluía tanto el dinero recaudado como el derecho a decidir a qué destinar las recaudaciones. En estas instancias de negociación las asociaciones vecinales se posicionaron como las portavoces del barrio frente a la Municipalidad y los verdaderos representantes de los intereses de los vecinos. De este modo, el análisis de estos espacios de entretenimiento barriales nos acerca a la cultura de los porteños, su sociabilidad y usos del tiempo libre y, a la vez, nos permite desentrañar algunas facetas de la relación entre la cultura y la política en las primeras décadas del siglo XX.

\section{Bibliografía}

Milita Alfaro. Memorias de la bacanal: vida y milagros del carnaval montevideano (1850-1950). Montevideo, Ediciones de la Banda Oriental, 2008.

Milita Alfaro. Carnaval. Una historia social de Montevideo desde la perspectiva de la fiesta, "El Carnaval heroico (1800-1872), Montevideo, Ediciones Trilce, 1991.

Mijail Bajtin. La cultura popular en la Edad Media y en el Renacimiento. Buenos Aires, Alianza, 1994.

Andrés Bisso. Sociabilidad, política y movilización. Cuatro recorridos bonaerenses (1932-1943). Buenos Aires, CEDINCI- Editorial Buenos Libros, 2009.

Andrés Bisso. “¿El de gaucho o el de Tom Mix? Reflexiones políticas a partir de los horizontes de identidades prestadas en disfraces y personificaciones lúdicas en la provincia de Buenos Aires durante los carnavales de la época fresquista, 19361940", en Andrés Bisso, Kahan, Emmanuel y Sessa, Leandro (Comps.), Formas políticas de celebrar y conmemorar el pasado (1930-1943), Ceraunia, La Plata, 2014. Peter Burke. "La traducción de la cultura: el carnaval en dos o tres mundos", en Peter Burke (Ed.). Formas de historia cultural, Madrid, Alianza Editorial, 2000, pp. 191206.

Hernán Camarero. A la conquista de la clase obrera. Los comunistas y el mundo del trabajo en la Argentina, 1920-1935. Buenos Aires, Siglo XXI Editora Iberoamericana, 2007, pp. 217-283.

Laura Caruso, "Carnavales proletarios: la huelga grande del Riachuelo y el carnaval al sur de la ciudad, Buenos Aires 1903-1904", ponencia presentada en el IV Taller "Historia Social, Género y Derechos", Instituto Interdisciplinario de Estudios de Género, Buenos Aires, 2017.

Adolfo Bioy Casares. El sueño de los héroes. Buenos Aires, Editorial Losada, 1954.

Oscar Chamosa. "Lúbolos, Tenorios y Moreiras: reforma liberal y cultura popular en el carnaval de Buenos Aires de la segunda mitad del siglo XIX", en Hilda Sábato y Alberto Lettieri (Comps.), La vida política en la Argentina del siglo XIX. Armas, votos y voces, Buenos Aires, FCE, 2003, 115-135. 


\section{Erica Cubilla}

Erica Cubilla. “Alcaldía de Contraventores o 'Cárcel de Villa Devoto?': representaciones en disputa en torno a un barrio porteño en los años treinta", en: Sandra Gayol y Silvana Palermo (Eds.). Política y cultura de masas en la Argentina de la primera mitad del siglo XX. Los Polvorines, Ediciones UNGS, 2018, pp. 125-148.

Roberto DaMatta. Carnavales, malandros y héroes. Hacia una sociología del dilema brasileño. México, FCE, 2002.

Luciano De Privitellio. Vecinos y ciudadanos. Política y sociedad en la Buenos Aires de entreguerras. Buenos Aires, Siglo XXI Editores, 2003.

Umberto Eco, Et. Al. Carnaval! México, FCE, 1989.

Alejando Espinosa Patrón. "Aproximación a una teoría de la fiesta del Rey Momo a partir de la triada comunicación, cultura y carnaval". Palabra Clave, Vol. 13, N1, 2010, pp. 175-188.

Juan Antonio Flores Martos. "Un continente de carnaval: etnografía crítica de carnavales americanos". Anales del Museo de América, 2001, pp. 29-58.

Ricardo Falcón. "Rituales, fiestas y poder (una aproximación historiográfica a un debate sobre su pasado y presente). Estudios Sociales, Revista universitaria semestral, año X, n 18, Santa Fe, 2000, pp. 89-101.

Ricardo Falcón. "La larga batalla por el carnaval. La cuestión del orden social, urbano y laboral en el Rosario del S. XIX". Anuario de la Escuela de Historia, n 14, segunda época, Rosario, UNR- Editora, 1989.

Milton Godoy Orellana. “Carnaval, disciplinamiento cultural y respuestas populares en Chile (Norte Chico, 1840-1900), en Ernesto Bohoslavsky y Milton Godoy Orellana (Eds.), Construcción estatal, orden oligárquico y respuestas sociales. Argentina y Chile, 1840-1930, Buenos Aires, UNGS/Prometeo, 2010, pp. 121-148.

Marianne González Alemán. “QQué hacer con la calle? La definición del espacio público porteño y el edicto policial de 1932". Boletín del Instituto de Historia Argentina y Americana Dr. Emilio Ravignani, n 34, Buenos Aires, enero 2012.

Adrián Gorelik. La grilla y el parque. Espacio público y cultura urbana en Buenos Aires, 1887-1936. Bernal, Editorial de la Universidad Nacional de Quilmes, 1998.

Francis Korn. Buenos Aires: los huéspedes del 20. Buenos Aires, Sudamericana, 1974. Capítulo V: “El Carnaval”, p. 205.

Leandro Losada. "Del carnaval al corso de Palermo: los ritos sociales de la élite porteña en la belle époque (1880-1910)". Jahrbuch für Geschichte Lateinamerikas, Alemania, Böhlau Verlag, 2007, pp. 259-280.

Leandro Losada. La alta sociedad en la Buenos Aires de la "Belle Epoque". Buenos Aires, Siglo XXI Editores, 2008.

Diego Roldán. "Imágenes, juegos, rituales y espacios. Las Interacciones socioculturales entre elites y sectores populares durante la entreguerras. La “incultura en Rosario (Argentina)”. História, São Paulo, 28, (2), 2009, pp. 683- 714; Diego Roldán. La invención de las masas. Ciudad, corporalidades y culturas. La Plata: Facultad de Humanidades y Ciencias de la Educación (UNLP), capítulo XI, 2015, pp. 223-237. 


\section{Buenos Aires en carnaval: los corsos del barrio de Villa Devoto en la década de 1930}

Diego Roldán. "Imágenes de un juego social y simbólico. Los carnavales rosarinos entre 1900 y 1945". Estudios Sociales, revista universitaria semestral, año XXI, № 40, Santa Fe, Argentina, primer semestre 2011, 2011.

Micol Seigel. “Cocoliche's Romp: Fun with Nationalism at Argentina's Carnival”. The Drama Review, Vol. 44, nํ2, 2000, pp. 56-83.

James Scobie. Buenos Aires. Del centro a los barrios 1870-1910. Buenos Aires, Ediciones Solar/ Hachette, 1977.

Juan Suriano. Anarquistas. Cultura y política libertaria en Buenos Aires, 1890-1910. Buenos Aires, Manantial, 2008, p. 154.

Fortunato Nicolás Troisi. La villa Devoto que vi crecer. CABA, Edición del autor, 1979. Fortunato Nicolás Troisi. La villa Devoto que vi crecer (segunda parte). CABA, Edición del autor, 1988.

\section{Fuentes}

Municipalidad de la Ciudad de Buenos Aires. Cuarto Censo General de Población. Municipalidad de la Ciudad de Buenos Aires. 22 de octubre de 1936.

Municipalidad de la Ciudad de Buenos Aires. Tercer Censo General de Población. Municipalidad de la Ciudad de Buenos Aires. 1909.

Municipalidad de la Ciudad de Buenos Aires. Memoria del Departamento Ejecutivo de la Municipalidad de la Ciudad de Buenos Aires, 1933- 1940.

Noticias Devotenses, 1932-1939, nº 1 a 333.

Recibido: 04/07/2018

Evaluado: 01/08/2018

Versión Final: 26/08/2018 